\title{
5. Enhancing the social partners and social dialogue in the new world of work in the Czech Republic
}

\section{Soňa Veverková}

\section{INTRODUCTION}

In this chapter we discuss social dialogue in the Czech Republic and its potential role in the new world of work. We present the views of Czech social partners on representativeness, autonomy, digitalization and the new world of work, as well as other topical issues that are currently being intensively addressed, such as eliminating inequalities concerning wages and working hours, and labour shortages.

While autonomy is not a current topic for the Czech social partners, representativeness and digitalization are more relevant. The question of representativeness is serious on the trade union side. Although over the past few years some trade unions have managed to stabilize their membership bases, the long-term decline in membership means that trade unions have less capacity for collective bargaining. Digitalization is a controversial topic: in general, both sides support this process, but the trade unions point out the potential risks and emphasize the need to regulate the process. The employers believe that digitalization will help to solve some of the problems they currently face, principally the severe labour shortage. Two other major issues are eliminating inequalities concerning wages and working hours, and labour shortages. The first, by its nature, is of more concern to trade unionists, but in some respects the employers also have something to say about it: they support wage increases in sectors such as education, social services and health care, among others. Also, shortening working hours without a decrease in wages is not a problem for many employers, as the second case study in this chapter shows. Labour shortages are closely interconnected with the issues of digitalization and labour immigration, to which both social partners strongly prefer digitalization.

Although the social partners have not always been in agreement on the issues under discussion, they generally adopt a consensual and non-confrontational behavioural style, and are ready to compromise. This is shown by the first case study. 


\section{INSTITUTIONAL FRAMEWORK FOR SOCIAL DIALOGUE AND COLLECTIVE BARGAINING IN THE CZECH REPUBLIC}

\subsection{Main Legislation}

The legislative process forming the legal framework for independent social dialogue and collective bargaining commenced as part of the revolutionary socio-economic changes at the start of the 1990s. The Czech Republic has no specific comprehensive legislation covering trade unions, employers' organizations and collective bargaining; instead, the legal relationship between these parties is provided for in a number of separate pieces of legislation. The basic legal provisions concerning industrial relations in respect of both trade unions and employers are contained in Act No. 23/1991 Coll., the Charter of Fundamental Rights and Freedoms, ${ }^{1}$ which provides for freedom of coalition and the right to associate and form unions. From 1990 to 2013, the establishment and existence of trade union organizations and associations was provided for in Act No. 83/1990 Coll., on the association of citizens. Since 1 January 2014, this subject area has been covered by the new Civil Code (Act No. 89/2012 Coll., the Civil Code²).

Other important legislation with regard to industrial relations includes Act No. 262/2006 Coll., the Labour Code, ${ }^{3}$ which provides the legal basis for negotiating collective agreements at the company and higher levels, and Act No. 2/1991 Coll., on collective bargaining, ${ }^{4}$ which regulates the collective bargaining process at the company and higher levels, as well as the settlement of collective disputes and the extension of higher-level collective agreements.

\subsection{Collective Bargaining System}

\section{Tripartite level}

In the Czech Republic, the Council of Economic and Social Agreement of the Czech Republic (Rada hospodářské a sociální dohody České republiky, RHSD) acts as the tripartite forum at national level; it is the country's main social dialogue institution. The task of the RHSD is strictly consultative. The aim of the tripartite organization is to reach agreement via a mutually respected form of dialogue in fundamental areas of economic and social development, and to maintain social consensus as a prerequisite for positive development of the economy, as well as the standard of living. Tripartite negotiations enable the government to keep continuous track of the views of trade unions and employer organizations, and they ensure that the social partners can present their views and obtain information from their partners at the tripartite level. Proof of the success of the tripartite organization's activities is provided - and internationally acknowledged by the long-term maintenance of social consensus, which has been highly important for economic stability and development in the Czech Republic (Veverková 2012). In the European context, the structure and organization of the Czech tripartite organization is standard in all respects (Vácha 2012).

The top negotiating body of the tripartite organization is the Plenary Meeting, where the government delegation is represented by eight members, employer organizations by seven representatives - namely, from the Confederation of Industry of the Czech 
Republic (Svaz průmyslu a dopravy České republiky, SP ČR) and the Confederation of Employer and Entrepreneur Associations of the Czech Republic (Konfederace zaměstnavatelských a podnikatelských svazů České republiky, KZPS ČR) - and union confederations also by seven members - namely, from the Czech-Moravian Confederation of Trade Unions (Českomoravská konfederace odborových svazů, ČMKOS) and the Association of Autonomous Trade Unions of the Czech Republic (Asociace samostatných odborů České republiky, ASO ČR). Criteria for participation are set out in the Statutes of the Council of Economic and Social Agreement of the Czech Republic ${ }^{5}$ (see section 3 in this chapter for details). The conclusions of the tripartite meeting are approved by all participants. If consensus is not reached and common conclusions are not accepted, the delegations' differing opinions on the issues at hand are published.

The matters on which the RHSD comments are defined by its Statutes: economic policy, labour relations, collective bargaining and employment, social issues, public service wages and salaries, public administration, safety at work, development of human resources and education, and the Czech Republic's position within the EU. From a European perspective, the Czech Republic is one of the countries in which tripartite concertation covers a wide array of activities.

There are also 13 regional tripartite bodies which deal with similar areas to those dealt with by the national body, as defined by their statutes.

\section{Collective bargaining}

Collective bargaining in the Czech Republic occurs at the company and the sectoral (or cross-sectoral) level. The company level is the most common. There is no collective bargaining at the national level. It is possible to conclude both higher-level collective agreements and company-level collective agreements. Both higher-level and company-level collective agreements are legally binding. Higher-level agreements serve as a framework or guide for the determination of company-level agreements; that is, higher-level agreements set out minimum standards with regard to wages and working time, which are subsequently adhered to in company-level agreements; company-level collective agreements can set out higher standards, but not lower. Company-level agreements cover all the employees at the workplace, no matter whether they are members of the trade union organization or not.

No register of company-level collective agreements (CLCAs) is maintained in the Czech Republic, however, higher-level collective agreements are monitored by the Ministry of Labour and Social Affairs (Ministerstvo práce a sociálních věcí České republiky, MPSV). Table 5.1 shows the number of higher-level collective agreements concluded in the period 2008 to 2018. Data on company-level collective agreements are not available, except for ČMKOS members, however, according to the social partners, the number of CLCAs concluded decreases every year.

It is evident from Tables 5.1 and 5.2 that the number of higher-level collective agreements concluded has remained largely unchanged. Higher-level collective agreements are usually concluded for a period of one year, although there is a growing tendency for the validity period to cover longer periods of time. Company-level collective agreements are usually concluded for a period of one year. 
Table 5.1 Number of higher-level collective agreements concluded during 2008-18, Czech Republic

\begin{tabular}{lccc}
\hline & $\begin{array}{l}\text { Number of higher-level } \\
\text { collective agreements }\end{array}$ & $\begin{array}{l}\text { Number of higher-level } \\
\text { collective agreements } \\
\text { extended }\end{array}$ & $\begin{array}{l}\text { Number of company-level } \\
\text { collective agreements concluded } \\
\text { by ČMKOS members }\end{array}$ \\
\hline 2008 & 25 & 4 & 3155 \\
2009 & 25 & 4 & 3082 \\
2010 & 22 & 5 & 4812 \\
2011 & 22 & 5 & 4904 \\
2012 & 24 & 4 & 4680 \\
2013 & 24 & 6 & 4739 \\
2014 & 24 & 4 & 3966 \\
2015 & 21 & 4 & 3910 \\
2016 & 23 & 4 & 3849 \\
2017 & 19 & 6 & 3767 \\
2018 & 22 & 5 & 3770 \\
\hline
\end{tabular}

Note: Data on CLCAs is for ČMKOS members only.

Source: Data on HLCAs, Ministry of Labour and Social Affairs of the Czech Republic (MPSV); data on CLCAs, ČMKOS.

Table 5.2 Collective bargaining coverage, Czech Republic, 2012-18 (percentage)

\begin{tabular}{lccccccc}
\hline & 2012 & 2013 & 2014 & 2015 & 2016 & 2017 & 2018 \\
\hline HLCA coverage & 15.8 & 15.2 & 13.7 & n.a. & n.a. & n.a. & n.a. \\
CLCA coverage & 33.9 & 33.2 & 31.3 & 31.6 & 30.4 & 31.2 & 31.5 \\
Collective bargaining coverage (ČSÚ) & 47.62 & 46.97 & 47.15 & 46.02 & 45.73 & 45.04 & 44.47 \\
\hline
\end{tabular}

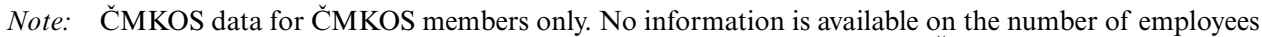
covered by higher-level collective agreements for 2015 and the following years ( $\breve{C} M K O S$ was unable to obtain these data from individual member trade union associations).

Source: Data on higher-level and company-level collective agreement coverage by ČMKOS. Data on collective bargaining coverage by Czech Statistical Office (Český statistický úrad, ČSÚ), based on Structure of Earnings Survey.

\section{Extension mechanisms}

A legal provision concerning mandatory extension is available, but is rarely invoked and applied regularly only in some sectors (construction, textiles and leather, transport and porcelain). The extension of a binding higher-level collective agreement to another employer is possible under conditions set out in Act No. 2/1991 Coll., on collective bargaining. The MPSV possesses the relevant powers to ensure that agreements are extended based on a proposal put forward by both parties to the agreement, provided that the conditions set out in legislation are met. No voluntary extension mechanisms exist. 


\section{Industrial action}

Czech law recognizes only two types of industrial action: strike and lockouts. In addition to these two types defined in Act No. 2/1991 Coll., on collective bargaining, in practice a strike alert is often used.

The right to strike, as a fundamental human right, is guaranteed in Act No. 2/1993 Coll. Charter of Fundamental Rights and Freedoms, which forms part of the Constitution of the Czech Republic. Article 27 (section IV) of the Charter states that the right to strike is guaranteed in accordance with the conditions laid down by law; this right is not held by judges, members of the armed forces and members of security forces. The legality of a strike is also limited by Act No. 2/1991 Coll., on collective bargaining which only covers strikes related to collective bargaining. Therefore, strikes can be divided into:

1. Strikes related to Act No. 2/1991 Coll., on collective bargaining - these strikes, their requirements and their procedure are precisely regulated by law. A strike, as understood by the Act is a legal instrument to settle collective disputes concerning the negotiation and conclusion of a collective agreement. A dispute on a change to an agreement already in force is also considered a collective dispute if the possibility and extent of changes has been agreed in a collective agreement.

2. Strikes outside the scope of Act No. 2/1991 Coll., on collective bargaining - there is no law in the legal code to implement the previously mentioned Article 27, concerning strikes other than strikes addressed in Act No. 2/1991 Coll., on collective bargaining. However, this does not mean that all types of strikes other than those addressed by the above-mentioned Act are prohibited - the court decides whether a particular strike is legal or not.

The definition of a lockout is a partial or complete stoppage of work by an employer, where the employer may, as a final solution for resolving a dispute about the conclusion of a collective agreement, declare a lockout. Lockouts have never been realized in the Czech Republic.

Strikes are relatively rare in the Czech Republic. Strike alerts are used more often, but this type of industrial action is not defined by law.

\subsection{Main Actors (Trade Unions and Employers' Associations)}

\section{Trade unions and workers' representatives}

Trade unions play the most significant role by far in relation to employee representation, not only in terms of competency, but also owing to their presence in the workplace and functions with regard to social dialogue, particularly collective bargaining. Only trade unions are entitled to represent employees when it comes to general labour relations, collective bargaining aimed at concluding collective agreements, and tripartite negotiations conducted in the context of a tripartite body.

Employees may also be represented by works councils (rada zaměstnancü) and representatives for occupational safety and health protection (zástupce pro oblast bezpečnosti a ochrany zdraví pri práci), but these bodies do not enjoy legal recognition and are entitled to act merely as mediators between employers and employees by enhancing consultation and the flow of information within a company. No national register of works councils or 
representatives for occupational safety and health protection exists; however, they would appear to be extremely rare.

\section{Main trade union confederations and federations}

There are three main trade union confederations in the Czech Republic (Table 5.3): the Czech-Moravian Confederation of Trade Unions (Českomoravská konfederace odborových svazů, ČMKOS, founded in 1993), the Association of Independent Trade Unions of the Czech Republic (Asociace samostatných odborů České republiky, ASO ČR, founded in 1995) and the Confederation of Arts and Culture (Konfederace umění a kultury, KUK, founded in 1996). These three trade unions represent around 79 per cent of trade union members in the Czech Republic (Kroupa et al. 2019). ČMKOS and ASO ČR are also members of the tripartite body.

From 2011 to 2018, the membership of the two biggest union confederations experienced a marked decrease: С̆MKOS lost 28 per cent of its members and ASO ČR as much as 45 per cent (Kroupa et al. 2019).

KUK stands out among these trade union confederations. It has maintained its federative form (included two Slovak trade unions) and covers many self-employed.

\section{Employers' associations}

Employers' interests are represented in national-level social dialogue in the Czech Republic by the two largest employer confederations, the Confederation of Industry of the Czech Republic (Svaz průmyslu a dopravy České republiky, SP ČR) and the Confederation of Employer and Entrepreneur Associations of the Czech Republic (Konfederace zaměstnavatelských a podnikatelských svazů České republiky, KZPS ČR), which are both members of the tripartite body.

Membership of these employers' organizations is voluntary and members are required to pay membership fees.

Table 5.3 Main trade union confederations and federations and their members, Czech Republic, 2001-18

\begin{tabular}{lrrrrrrrr}
\hline & \multicolumn{1}{c}{2001} & \multicolumn{1}{c}{2011} & \multicolumn{1}{c}{2013} & \multicolumn{1}{c}{2014} & \multicolumn{1}{c}{2015} & \multicolumn{1}{c}{2016} & \multicolumn{1}{c}{2017} & \multicolumn{1}{c}{2018} \\
\hline ČMKOS & 900000 & 407000 & 366741 & 333309 & 286768 & 297762 & 295555 & 292525 \\
ASO ČR & 200000 & 150000 & 107000 & 95000 & 80000 & 78000 & n. a. & 85000 \\
KUK & 90000 & 35482 & 32158 & 32095 & 31549 & 30825 & 30214 & 29715 \\
\hline
\end{tabular}

Note: Years 2001 and 2011 for comparison.

Source: $\quad \check{C} M K O S$, ASO ČR and KUK. 


\section{STRENGTHENING THE REPRESENTATIVENESS OF SOCIAL PARTNERS AND INCREASING THEIR INSTITUTIONAL CAPACITY TO SHAPE LABOUR MARKETS THROUGH SOCIAL DIALOGUE AND CONSULTATIVE PROCESSES}

Czech law does not lay down any representativeness criteria for either trade unions or employer organizations, with the following exceptions:

1. at the company level at which a trade union is entitled to operate and has the right to associate only if it has at least three members who are in an employment relationship with the company; ${ }^{6}$

2. in connection with the possibility of participating in Council of Economic and Social Agreement (RHSD) negotiations (see below); or

3 . in connection with the extension of higher-level collective agreements, which is, however, applied only rarely (requests to extend higher-level agreements must be made by the largest trade union or the largest employers' association in the sector to which the agreement is supposed to be extended ${ }^{7}$ ).

Since legislation does not impose any further requirements concerning social partner representativeness, they are not compelled to be representative; moreover, the topic of representativeness has not arisen in the public debate. ${ }^{8}$ The exception concerns a plurality of trade unions at the workplace when it comes to the procedure for concluding companylevel collective agreements. The current solution in these cases, as set out in the Labour Code, ${ }^{9}$ as amended, stipulates that if there is more than one trade union operating in a company, the employer must negotiate the collective agreement with all of them, regardless of the number of members the trade union has in the workplace. The trade unions are required to deal with the outcomes considering all employees jointly and in concert, unless agreed otherwise between the employer and the unions. However, this situation can lead to a number of complications: in certain sectors in which several trade unions are traditionally active in the workplace (health care, railways and air transport), it is not uncommon for one of the trade unions to obstruct the collective bargaining process for a considerable time. Cases have even been recorded of the company management establishing a trade union itself with the sole intention of obstructing collective bargaining (Léko, 2016). Therefore, ČMKOS initiated the introduction of an amendment to the Labour Code which aimed to revert to the situation that prevailed prior to 2008, which allowed the employer, where agreement could not be reached among the trade unions, to conclude a collective agreement with the trade union organization with the most members (the majority principle). The Constitutional Court (Ústavní soud České republiky), however, annulled this legislative change in $2008 .{ }^{10}$ However, even the previous legislation, which was introduced by the Labour Code in 2007 and was valid until the issuance of the aforementioned Constitutional Court judgment, was criticized in view of concerns that the largest unions in the company were able to pursue collective bargaining by blocking the process until the employer negotiated a collective agreement with them only. In effect, the trade union with the largest number of members overall, even though it had only a minority of union members in the company in question, could conclude a collective 
agreement without reference to the other union organizations. To date, however, the legislation as confirmed by the Constitutional Court ruling is still valid; that is, the employer must negotiate a collective agreement with all the trade union organizations active at the workplace.

Conversely, the representativeness of members of the RHSD is not the subject of public debate, even though at least one organization no longer meets the representativeness criteria as set out in the RHSD statutes, whose annexes ${ }^{11}$ precisely define the rules under which employee and employer organizations may participate in RHSD meetings. Representativeness criteria were first numerically defined in May 1995: the employer side was required to represent a total workforce of at least 500000 employees and the trade union side at least 300000 members. This regulation was criticized immediately by the smaller trade union confederations, who felt discriminated against. Further changes were introduced with the adoption of new Statutes in 1997 and again in September 2000.

The participation of KUK, which was agreed during the establishment of the RHSD, even though it does not meet the representativeness criteria, gradually became a historical anachronism (Hála 2002). However, changes to the Statutes of September 2000 introduced the condition that the trade union entity must associate at least 150000 trade union members (still valid today). This change subsequently enabled the ASO ČR to become a member of the RHSD in place of the KUK. According to a KUK representative, the reason for this change was not only the application of the numerical representativeness criterion, but rather a more complicated problem in terms of relations with ČMKOS: KUK members often express interests in conflict with those of the ČMKOS. ${ }^{12}$ The KUK's position as a national trade union confederation has deteriorated considerably since leaving the tripartite body, although it remains a legislative commentary organization and is contacted both formally and informally by public institutions on sector-related matters.

In this context, it should be noted that the ASO ČR, which became a member of the RHSD owing to the amendment of Annex 2 of the Statutes in 2000 and thus replaced the KUK ČR, ceased to meet the representativeness criteria in 2012 (owing to a gradual decline in its membership). It remains a member of the tripartite body, however, as no one has challenged it, nor have there been any other candidates for RHSD membership. Although the KUK could theoretically re-apply for RHSD membership, its president explained that is not being considered, given that the confederation no longer has the capacity to participate in tripartite negotiations (Húska 2019).

Czech legislation does not set out any other regulations regarding social partner representativeness. However, the long-term decline in union membership (employers do not face a similar problem; their membership base has remained stable over the long term see Table 5.4) may present the unions with complications in the future. If workers are not interested in trade union membership, it is not possible to conduct sophisticated social dialogue. Although both the ČMKOS and the ASO ČR have seen an increase in new members since around 2015 and confirm a growing interest ${ }^{13}$ that at least compensates for departing members, ${ }^{14}$ it is still too early to assess whether this represents a long-term trend and whether it will be sufficient to arrest the overall decrease in union membership. However, the trade unions do not consider the number of members to be the only influencing factor; they also stress, in particular, the capacity to act (Vejvodová 2019a). Moreover, the qualitative development of trade unions is an important factor, which is 
Table 5.4 Trade union and employer organization density, the Czech Republic, 2012-18 (active employees, percentage)

\begin{tabular}{llllllll}
\hline & 2012 & 2013 & 2014 & 2015 & 2016 & 2017 & 2018 \\
\hline Trade union density & 14.8 & 13.6 & 12.8 & 12.0 & 12.0 & 11.7 & 11.5 \\
Employer organization density & 57 & 61 & 64 & 63 & 61 & 61 & 60 \\
\hline
\end{tabular}

Note: Author's calculation based on data from ASO ČR, ČMKOS, KUK, KZPS ČR, SP ČR.

associated with a gradual change in style. Since 2010, the unions have promoted a professional approach in relation to a number of aspects of their work, including marketing and high-quality self-presentation, accompanied by a non-confrontational, consensual negotiation style (Vejvodová 2019a).

\section{Trade union membership for the self-employed}

In connection with their decreasing membership, there is occasionally a public debate on whether unions might also enhance their representation of the self-employed, a group of people who, since they are not employees, do not enjoy the protection of the Labour Code and usually do not have the financial or personnel capacity to become members of employers' associations. Czech legislation does not limit trade union membership to employees. The KUK, in particular, has extensive experience with trade union membership of the self-employed; this group even predominates in some of its member unions (Horváthová 2019). The problem with this arrangement, however, is that the self-employed cannot collectively negotiate the price of their work because they are entrepreneurs not employees, and any agreement on prices violates competition legislation (Horváthová 2019; Húska 2019). Thus, while the self-employed can be members of trade unions and membership provides undoubted benefits - in particular, concerning enhanced awareness of, for example, new legislation in the relevant sector and the potential to influence it - the law does not allow them to conduct collective bargaining. Nevertheless, the self-employed cannot be expected to compensate for declining employee membership.

\section{Anonymous trade union membership}

A new phenomenon that has emerged involves anonymous trade union membership in 'groupings of members' (seskupení členü). This could well motivate workers whose employers are opposed to trade unions to establish a union in their workplace. In 2013, the Czech Metalworkers' Federation $\left(\mathrm{OS} \mathrm{KOVO}{ }^{15}\right)$, the largest member of the ČMKOS, introduced the concept of anonymous membership, the aim of which was to increase the level of interest in the union among specific groups of employees and to enable the creation of trade unions at companies where the management is opposed to them. According to the newly amended Articles of Association of the OS KOVO, ${ }^{16}$ groupings of members, which are not institutionally established in legislation and are not legal persons, are empowered to represent employees' interests in companies where there is no trade union representation. Despite the legal anomaly, however, the existence of these groupings is allowed via the OS KOVO's Articles of Association. The groupings must consist of at least three employees who are in an employment relationship with the employer (the same 
legislative requirement as when establishing a basic trade union organization at the workplace). The grouping contacts the OS KOVO regional office which, in turn, appoints a professional trade unionist who negotiates with the employer. If they prefer, the members are entitled to remain anonymous. According to the OS KOVO, this approach enjoys a number of benefits that even trade unionists who do not need to remain anonymous might take advantage of: the establishment of a grouping of members is administratively simpler than setting up a standard trade union, and a professional trade unionist negotiates with the employer, which puts fewer demands on normal employee union representatives in relation to knowledge of legislation and collective bargaining.

Employers are generally against the establishment of such groupings. The Korean company Daechang Seat, refused to acknowledge this grouping of members as a trade union and filed a lawsuit against the OS KOVO, alleging that the grouping does not meet the legal requirements covering the operation of a trade union. In February 2018, however, the Supreme Court of the Czech Republic (Nejvyšši soud České republiky) ruled that the grouping of members enjoyed the same status as a public trade union and that the employer must accept this form of association and treat it in the same way as a regular trade union, including with regard to collective bargaining. ${ }^{17}$ According to the OS KOVO, groupings of members are active in 70 companies and involve 3000 persons.

However, it is necessary to distinguish this phenomenon from virtual or 'secret' trade unions, which have emerged over the past two years (Vejvodová 2019b). These trade union organizations are not based on company premises but on the Internet. They also recruit members through websites and social networks, often offering a financial incentive to new members. Although the Labour Code requires a minimum of three employees in an employment relationship with the employer for the formation of a trade union organization, it is not mandatory to state the members' names. The trade union then informs the employer that a trade union has been established in the company and that it was formed by three of the company's employees; no proof is required. ${ }^{18}$ Employers assert that these trade unions exploit the unions' right, by law, of access to information that is not normally publicly disclosed by the employer and use it for industrial espionage purposes or to disrupt social peace for competitive purposes. One characteristic feature of these virtual trade unions is that they do not enter into collective bargaining with the employer (Vejvodová 2019b). However, many employers are reluctant to disclose their experiences with virtual trade unions because they fear being accused of refusing to respect the compulsory requirement to cooperate with trade unions. While no data are available on this phenomenon, the SP ČR is working with its members on this issue, and a number of employers are considering taking virtual trade unions to court.

\section{SUPPORTING THE AUTONOMOUS ROLE OF THE SOCIAL PARTNERS}

According to trade union and employer representatives, in the Czech Republic there is no need to address the issue of social partner autonomy. The social dialogue system was established in the 1990s and has not been subjected to any significant changes; both trade union and employer representatives consider that the system is functional and effective (Drbalová 2019; Samek 2019). 
As far as the financing of social dialogue is concerned, in addition to membership fees collected from trade union members and employers who are members of an employers' association, the state also contributes to the financing of social dialogue. In addition, a technical amendment to the Labour Code, effective from 2005, extended its scope to include state support for social dialogue. It consisted of a new provision containing an explicit regulation under which the state meets the costs of social dialogue conducted by the social partners at national and regional levels under the conditions (and in the amount) agreed annually by the RHSD. ${ }^{19}$ Based on the methodological procedure for the disbursement of funding for the support of social dialogue adopted by the RHSD, the social partners represented in the RHSD submit proposals for projects, specifying the required funds and the purpose of their use. Following discussion and approval by the RHSD, the agreed funding is paid out by the MPSV.

At corporate level, trade union operations are regulated by the Labour Code. The employer is obliged to create conditions at its own expense for the activities of employee representatives, in particular to provide them with adequate facilities according to their operational capacity and to cover the necessary maintenance, technical and material costs. $^{20}$

Social partner autonomy is also reflected in their ability to implement autonomous European framework agreements. However, in the Czech Republic the basic provisions of negotiated agreements are usually implemented through generally binding legal regulations (especially the Labour Code); this approach is also generally applied by the social partners. Nevertheless, the ČMKOS is striving to have the basic provisions of such European framework agreements enshrined in legislation (especially in the Labour Code). However, this can occur only incrementally since such provisions must be part of the legislative process, involving a number of parties whose interests often differ considerably. The social partners agree that the priority interest is the use of collective agreements for this purpose, whether they are company- or higher-level agreements (ČMKOS 2019a). However, this has not been successful over the long term owing to the low employee coverage of both types of agreement, which makes it impossible to extend the obligations arising from autonomous agreements to all, or at least the majority of, employees. Another reason is the lack of interest among the social partners, especially at the company level, in implementing the provisions of autonomous framework agreements in their company- or higher-level collective agreements. Although the ČMKOS annually calls on its member associations to devote more attention to the implementation of framework agreements, the results are still poor: in 2019, more detailed conditions concerning the elimination of work-related stress were implemented in only 0.3 per cent of CLCAs, while conditions (procedures) concerning harassment and violence in the workplace have been implemented in just 1.4 per cent of these agreements (Trexima 2019).

\section{SOCIAL PARTNERS AND DIGITALIZATION}

The topic of digitalization ${ }^{21}$ is being approached by the public authorities in the Czech Republic with a relatively high degree of intensity. Individual government departments are well aware that the challenges and impacts of digitalization not only concern the production sector, but also that it is necessary to focus on the changes that digitalization is 
bringing about across the board. Action in this area is essential in the interests of maintaining social peace in the future, as well as ensuring long-term, stable, and harmoniously sustainable growth across the economy (Šulc 2017a).

Digitalization and its various impacts on society are being addressed as part of the Society 4.0 agenda. ${ }^{22}$ The coordinator of the digitalization agenda is the Office of the Government of the Czech Republic (Úřad vlády České republiky), which is striving to connect the various activities of individual ministries in this area. The Alliance Society Platform 4.0 (Aliance Společnost 4.0) has been created to provide a platform for cooperation between the state authorities, economic and social partners and academia. While the Alliance is a government initiative, the aim is to include all the relevant stakeholders in order to exploit the mutual synergies and potential of the Fourth Industrial Revolution and thereby increase the competitiveness of the Czech economy and bring about positive social change. The 'Action Plan for Society 4.0' ('Akční plán pro Společnost 4.0') document, which summarizes the direction of government policy and key measures to support the development of the digital market in the Czech Republic, forms the umbrella document for the Alliance Platform. The government is preparing specific grant schemes to provide financial support for research and development projects based on the approved concept.

The government consults the social partners on a regular basis concerning strategy documents on digitalization (Drbalová 2019; Samek 2019). The largest social partners even have their own specialists on the development of the digital economy (for example, the SP ČR and the ČMKOS). The trade unions, in particular, see their role as identifying future trends in the composition of professions in the digital economy. According to union representatives, employees need to be prepared for the coming changes and enabled to adapt or increase their chances of new employment if they lose their current jobs. The trade unions also regard discussions with employers as essential, with a view to anticipating human resource (HR) strategies at company level (Kyzlinková et al. 2017), including changes to the education system (see section 6 in this chapter).

In addition, the trade unions believe that presently, despite the various forecasts and analyses, it is not possible to fully anticipate the effects of digitalization, such as when exactly and to what extent it will affect our lives (Kyzlinková et al. 2018). However, this unpredictability, according to Samek (2019), is serving to diversify the trade unions' approach beyond the creation of strategies and action plans. Samek further believes that the trade unions should 'observe, analyse and then solve'. As an example, Samek (2019) cites platform work and Uber: initially Uber was considered to form part of the shared economy, with drivers offering free capacity in their cars; however, over time, this form of earnings became a standard business model that bypassed tax legislation and provided unfair competition to established (and regulated) taxi services. Moreover, it developed into a form of precarious employment owing to the non-standard working conditions. Hence, many countries have introduced substantial regulations in relation to this business and employment model. While these changes cannot be foreseen accurately, the trade unions believe that it is necessary to react to these developments and to introduce appropriate legislative limits for these forms of employment (business activities).

In general, the social partners are aware of the importance of digitalization and the changes that it will bring about. While both sides support this process, the trade unions, in particular, note the potential risks that digitalization entails, especially job losses, 
potential precarious employment and social inequalities, and emphasize the need to regulate the process (ČMKOS 2017; Kyzlinková et al. 2018). The employers believe that digitalization will help to solve some of the problems they currently face (for details see section 5 in this chapter), principally the severe labour shortage that would be eliminated by robotization (especially concerning night work and physically demanding work), while the trade unions identify the potential for transforming the Czech economy, which they believe is still based on the cheap-labour model, into a high-technology economy, thus solving the biggest problems they currently face, namely, low wages and low labour productivity.

A further, and already visible, consequence of digitalization (information and communication technology, ICT, development) concerns new (flexible) forms of employment. This includes ICT mobile work, platform work, job sharing and employee sharing. In general, employers welcome the increased flexibility in the labour market because it provides them with the opportunity to better adapt to the volume of orders and to work more efficiently with the workforce, thus enabling the more efficient allocation of work tasks.

Trade unions' attitude to the new forms of employment is significantly less optimistic. They perceive this issue ambivalently. While they are aware of the potentially positive aspects of certain new forms of employment for the workforce and the labour market (positive flexibility that allows for the harmonization of work and private life, the employment of hard-to-employ groups in the labour market, new job opportunities - see, for example, ČMKOS 2017), they see their role as pointing out the various negative aspects and determining ways to prevent the negative consequences associated with changes in forms of work organization. Increased labour market flexibility results in both opportunities and threats for employees, depending on the business cycle and the stage employees have reached in their lives. In the ascending phase of the business cycle and the consequent shortage of labour, employees wield bargaining power and are in a good position to insist on their demands. In economic downturns, however, the same working conditions may become disadvantageous if forced upon the employee by the employer (for example, involuntarily working from home if, for example, the employer wishes to save on the costs of renting office space). Moreover, trade unions are also concerned about the growing number of self-employed who do not pay social insurance contributions, that is, digital precariousness (ČMKOS 2017).

The various trade union confederations are also aware that the changes that are likely to result from the nature and organization of the digital economy will force them to both restructure and change their communications with, and approach to, current and potential members. The traditional sectoral organization model will be abandoned and standard employment patterns are likely to be replaced by more flexible and unstable forms of employment that will not provide the appropriate conditions for the joint organizational approach. Also, the conditions governing collective bargaining and collective agreements will need to change. The ASO's president, Bohumír Dufek, has referred to these agreements as new generation collective agreements, which will have to take into account ongoing labour market changes and ensure that employees are better able to adapt. That is, collective agreements will have to consider, for example, opportunities for further training and skill enhancement (Kyzlinková et al. 2018). 


\subsection{Work Outside the Employer's Workplace}

The most frequently discussed new form of employment in the Czech Republic is work outside the employer's workplace (ICT mobile work and home office). Working outside the workplace imposes considerable demands on employers and employees. It offers employees greater flexibility and increased opportunities to better reconcile their work and private lives. For many employers, the main motivation for introducing this form of employment is to save costs (office space and energy), but large companies often provide this option as an employee benefit (Kyzlinková et al. 2018). However, the trade unions tend to insist that working outside the workplace is not an employee benefit. They claim, for example, that it is a slippery slope to the employer requiring employees to be on-call and to perform work tasks whenever required instead of respecting normal working hours (Holanová 2016). The unions also draw attention to the cost-shifting aspect, as, for example, energy and IT costs - among others - are passed on to the employee. In their view, the employer should be expected to contribute towards such costs. $^{23}$

Also, working outside the employer's workplace requires the employer to address the legal and safety aspects of alternative forms of employment. ${ }^{24} \mathrm{~A}$ discussion is currently under way in the Czech Republic concerning, particularly, health and safety at work issues of working outside the workplace. Current legislation does not adequately address this. As regards health and safety, while the Labour Code does not allow any exemption from the employer's obligations to the employee, given the nature of home or mobile working, it is objectively impossible for the employer to fully comply with all the obligations imposed by legislation. There are two particularly problematic aspects:

1. The employer's limited control over the employee since they cannot enter the place of work, which may be the employee's residence, without the consent of the employee (or other entity), which is a serious problem with regard to compliance with occupational health and safety regulations.

2. Potential claims for damages by employees working outside the workplace, particularly in respect of work injuries: it is difficult to prove whether the injury occurred at work or not. Legislative attempts to change the situation have, to date, been unsuccessful. ${ }^{25}$

\subsection{The Shared Economy}

Another topic currently under discussion in the Czech Republic is the shared economy and the employment opportunities it generates (often referred to as platform-based working, crowd-working or digital freelancing). In mid-2017, eight companies operating in the shared economy founded the Czech Shared Economy Association (Česká asociace sdílené ekonomiky, ČASE), which actively cooperates with the various strategic players in the labour market. In 2018, ČASE and other experts participated in the compilation of an important development document of the Chamber of Commerce of the Czech Republic (Hospodářská komora České republiky, HK ČR), titled 'Recommendations for the development of the shared economy' ('Doporučení pro rozvoj sdílené ekonomiky'). This document contains 50 recommendations on how to approach regulation 
of the shared economy. Three main areas were identified that should be subject to regulation: entrepreneurship, tax and other deductions, and consumer protection. The most important point was the need for an unambiguous definition of income from occasional gainful employment and business activities by introducing a financial limit. ${ }^{26}$

In addition, the government presented the first detailed analysis of the shared economy and its potential regulation in 2017, and continues to take a close interest in this topic. The 'Analysis of the shared economy and digital platforms' ('Analýza sdílené ekonomiky a digitálních platforem') released by the European Affairs Section of the Office of the Government of Czech Republic (Sekce pro evropské záležitosti Úřadu vlády ČR 2017) analyses three approaches to regulating the shared economy: (1) maintaining the status quo, (2) partial changes in legislation and (3) comprehensive anchoring of the shared economy and related earnings in legislation. It highlights the advantages and disadvantages of each approach.

In general, the social partners are against regulatory approaches that would lead to the banning of new market mechanisms related to the shared economy, and would prefer to see partial changes to the regulatory environment. Economists and analysts from finance and consulting companies tend to share the view that fair and equal conditions and an environment that favours fair competition need to be established. However, these conditions cannot be achieved through the restrictive regulation of the shared economy, but via a certain loosening of regulation in other (standard) branches of the economy (Tüma 2016; Vyoral 2017). Restrictions will only lead to the transfer of these services outside the welfare system and the control of the state. Thus, employers tend to agree with those who suggest that 'the state should treat the matter delicately through dialogue with those involved in the provision of services in the shared economy' (Tüma 2016). Also, in the current legal environment it is essential that legislation be interpreted uniformly by all institutions.

The trade unions are concerned primarily about those employees who perform platform-based work for remuneration that barely meets minimum wage levels, especially given the time costs of searching for, and securing, fragmented work assignments and wage reduction pressure in the global labour market. A study commissioned by ČMKOS (Šulc 2017b) notes that the trade unions, which have consistently fought against the Švarc system phenomenon, are now being faced with the 'turbo Švarc system', ${ }^{27}$ that is, second-generation Taylorism. The unions stress that this new branch of the national economy is not subject to traditional regulation - for example, labour legislation and tax and social and health insurance obligations - and that the legal protection of platform-based dependent work is needed to cope with numerous hazards that might result in future upheavals affecting the very core of employees' legal certainty (Šulc 2017b). Legal analysis (Boháč et al. 2017, p. 336) cites repeated instances of noncompliance or circumvention of financial regulations in a number of branches and platforms (in particular, non-compliance with tax obligations) and the disregarding of administrative regulations (it is common to conduct business without the appropriate trade licence). Moreover, from the labour law perspective, it is clear that employment regulations are being violated both by platforms themselves and by other entities that take advantage of the anonymity of platforms and their unwillingness to share data with the state authorities. 


\subsection{Availability of ICT Technologies and Competition}

The KUK is currently monitoring a serious issue affecting part of its membership, namely trade unions representing workers in the art, culture and other creative sectors (cameramen, sound engineers, editors, translators and interpreters). With falling information technology (IT) fees and expanding IT connectivity, ICT technologies are now widely available to almost everyone, which has led to a substantial increase over the past ten years in amateur competition in a number of creative industries, the consequences of which are decreasing prices and decreasing production quality. The KUK has not yet determined the best approach to addressing these competition issues (Horváthová 2019; Húska 2019).

\section{SOCIAL PARTNER ISSUES AT NATIONAL LEVEL}

\subsection{Eliminating Inequalities in the Labour Market}

According to Samek (2019), the critical trade union role at present is the elimination of labour market inequalities. Inequalities of working conditions (wages, working hours and employee benefits) are linked to most of the negative phenomena evident in the Czech labour market, that is, economic migration, the brain drain and the grey economy. Currently, ČMKOS's most important policy efforts are directed towards ending the cheap labour economic model in the Czech Republic. The campaign to end the cheap labour model concerns two areas in particular in which, according to the trade unions, the differences between the Czech Republic and more developed European Union (EU) countries are most marked, namely, wage levels and working hours.

\section{End of cheap labour}

The 'End of Cheap Labour' campaign ('Konec levné práce') was launched by the ČMKOS in 2015. The aim of the campaign is to demonstrate that 'wage development in the Czech Republic is starting to become a serious economic problem' (ČMKOS 2015) and that the real convergence (wage convergence in particular) of the Czech economy towards those of more developed EU countries should proceed as quickly as possible. Only a major shift in economic policy could direct the Czech economy towards efficiency improvements, rapid growth and increased competitiveness (Fassmann and Ungerman 2015).

In 2014 - that is, prior to the launch of the 'End of Cheap Labour' campaign - median gross hourly earnings in the Czechia (the Czech Republic) were around one-third of those of the European median (Figure 5.1).

According to an analysis conducted by the trade unions (Fassmann and Ungerman 2015), this is the result of three main factors:

1. The approach adopted to the Czech Republic's economic transformation after 1989 and the 'transformation cushions', when the initial rate of the Czech crown was significantly undervalued in respect of the purchasing power parity in 1990, and Czech wages at the beginning of the transformation period (1991) - in exchange 


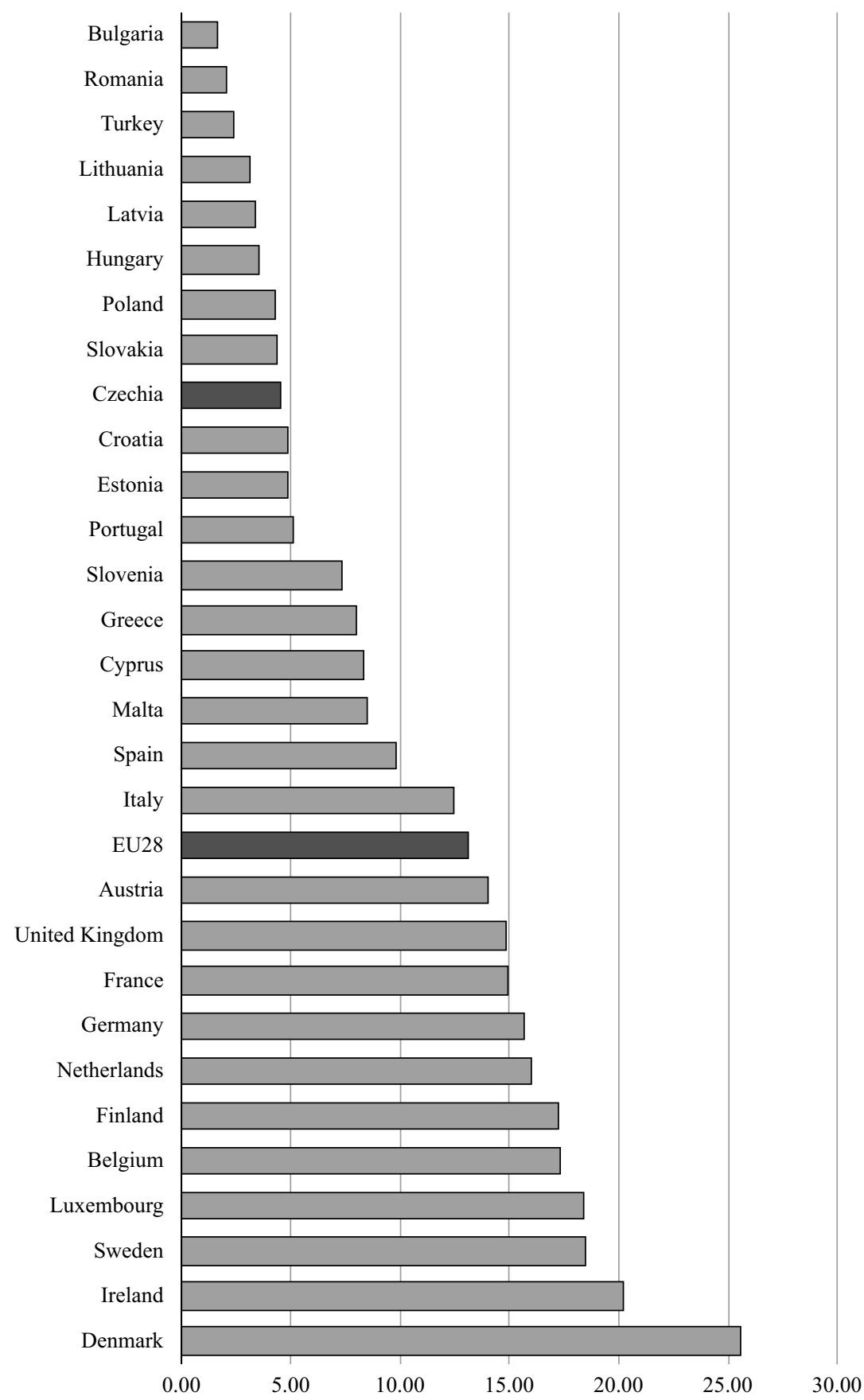

Figure 5.1 Median gross hourly earnings 2014 ( $€$ ) 
rate conversion terms - amounted to a fraction of those of Western countries (for example, a mere 10 per cent of the wage level in Germany). A further impact concerned the significant wage depreciation (labour costs) in the national currency below labour productivity levels. Price deregulation and inflation (56 per cent) led to a depreciation in savings and a decrease in real wages of 30 per cent.

2. The introduction of processes that deliberately distanced wage-setting mechanisms from practices applied in developed EU countries (a reduction in, or elimination of, collective bargaining; a significantly lower emphasis on tripartite dialogue at the national level; obstruction of the ratification of the European Social Charter and certain International Labour Organization (ILO) conventions; non-extension of higher-level collective agreements; and restriction of social dialogue at all levels) and a policy of lowering social standards (significant reductions in non-wage labour costs in the private sector, for example, reductions in the cost of corporate training, reductions in, or the abolition of, corporate social funds and cuts to social protection systems and employee legal protection, for example, the conditions governing dismissal, statutory limitation of working hours, safeguarding of collective bargaining and so on).

3. The restrictive economic policy long applied in the Czech Republic (with the exception of the eight-year period from 1998 to 2006).

Fassmann and Ungerman (2015) also present economic policy recommendations concerning how to remedy the situation based on strengthening the Czech currency and wage growth, which, they suggest, should increase more rapidly than in developed European countries in order to ensure convergence rather than further divergence.

The Fassmann and Ungerman (2015) analysis was adopted as the basis for ČMKOS's aforementioned 'End of Cheap Labour' campaign, which was supported from the outset by the second largest Czech trade union confederation, the ASO ČR, and the European Trade Union Confederation (ETUC). The campaign culminates every year in a meeting of trade unions at which the results of the campaign are presented and the objectives are set for the following year, particularly as regards wages. The ČMKOS issues recommendations for its members on an annual basis concerning increases in nominal wages, which the social partners subsequently negotiate in the form of collective agreements (either higher-level or company collective agreements). Table 5.5 illustrates how the recommended targets have changed. During 2010-14, when the Czech economy was struggling with the consequences of the global economic crisis, the ČMKOS did not issue any collective bargaining wage targets; indeed, it recommended that collective bargaining should respect the economic situation in the sector/company and, over the short term, even tolerate wage freezes if it helped to maintain employment levels in the company (ČMKOS 2010). However, in 2014, once it became clear that the Czech economy had emerged from the crisis, the ČMKOS began to issue recommendations on wage development.

Table 5.5 illustrates that both nominal and real wages have been increasing since 2014; in some years on average more than the unions demanded. However, no independent study has been conducted that analyses the extent to which wage growth in the Czech Republic has been influenced by trade union demands and the extent to which it is merely a consequence of economic growth, low unemployment rates and an acute labour shortage. 


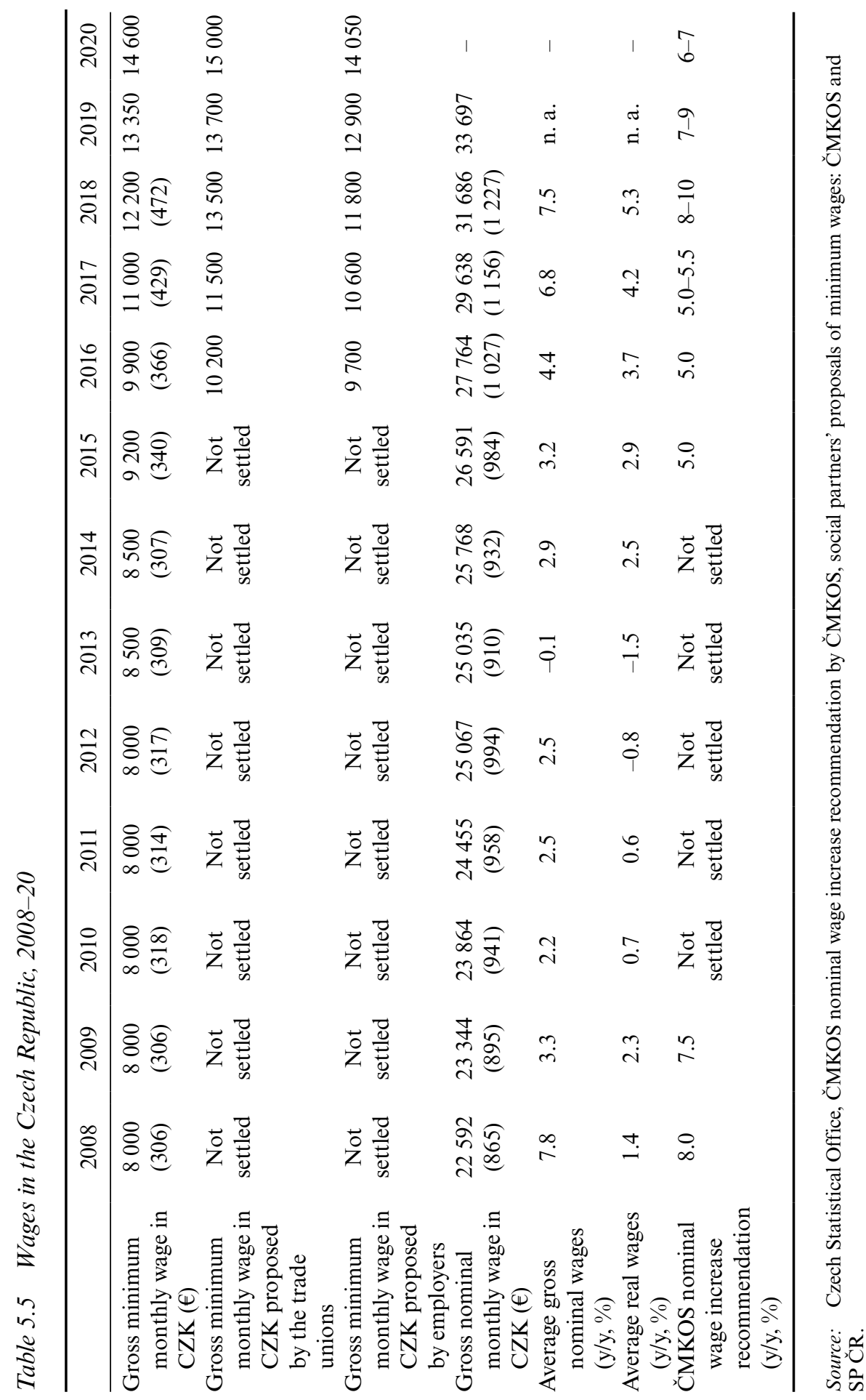


Employers disagree with the trade union demands regarding wage growth (Čížek 2015), considering them unrealistic. They base this on the low level of labour productivity (Trexima 2016a; Petrríček 2018). While labour productivity in the Czech Republic is indeed lower than in most developed EU countries (see Figure 5.2), the trade unions argue that this is not because Czech employees are less efficient, but because of the Czech economic model, orientated towards the production of goods with low added value (assembly plant production, montovna in Czech). This model was established in the 1990s when the Czech economy, which was in transition, was unable to compete with Western European countries. Moreover, the inclusion of the Czech Republic in global value chains as a producer of low value-added goods severely restricted corresponding growth in wages (Bittner et al. 2018). Thus, the solution is to re-orientate the Czech economy towards the production of higher added-value products (Kovanda 2018).

While employers agree that the re-orientation of the economy towards higher added value production is necessary, they also stress the importance of automation and robotization, which would free up lower-paid unskilled workers so that they could be trained to perform skilled, and thus more highly paid, work (Petříček 2018).

\section{Minimum wage}

The 'End of Cheap Labour' campaign also includes trade union demands concerning increases in the minimum wage. The minimum wage is set in the Czech Republic by government legislative decree. Although the government discusses the minimum wage with social partners at the RHSD, it alone decides on the amount, according to the prevailing economic situation. Employers agree in principle with increases in the minimum wage (Trexima 2016b; KZPS 2019); however, they demand that it be increased systematically, instead of sporadically as has been the case to date. According to the employers, minimum wage increases should be both transparent and predictable which, they argue, is not possible under the current minimum wage determination system.

While both the government and the social partners agree that the minimum wage should, ideally, depend on the average wage, to date they have been unable to agree on the ratio between the average wage and the minimum wage.

\section{Reduction in working hours}

In 2017, the ČMKOS added a new demand to the 'End of Cheap Labour' campaign, namely, shorter working hours without corresponding wage reductions. According to the trade unions, the ideal working time is 37.5 hours per week (instead of the current 40 hours stipulated by the Labour Code) and holiday entitlement should be five weeks per year (currently five weeks under the Labour Code). The trade unions argue that Czech employees work more hours in their lifetimes than do those in more developed EU countries (Fassmann et al. 2018). The trade unions demand that this aim be achieved initially via collective bargaining, with its incorporation in legislation following in the medium term (4-5 years). They argue that 77.3 per cent of company collective agreements, which set out uniform working hours throughout the respective companies, already include a weekly working time of 37.5 hours per week (Trexima 2018). The same applies to holiday entitlement: in 2018, this was extended by one week (to five weeks) in 76.7 per cent of company agreements and by two weeks (to six weeks) in 2.4 per cent of company 


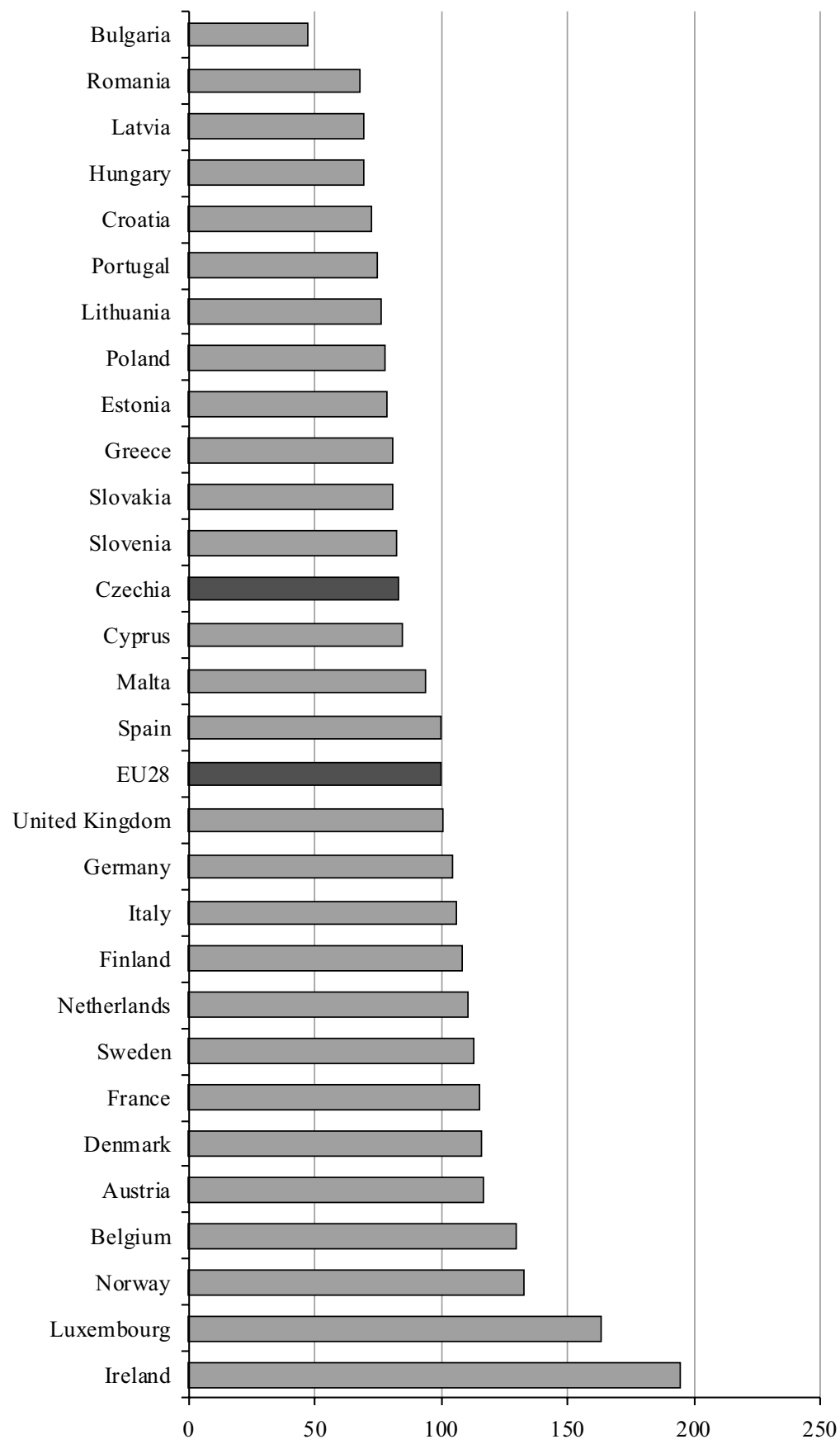

Note: $\quad$ EU28 $=100$ per cent.

Figure 5.2 Labour productivity per person employed and hours worked in 2018 (percentage) 
agreements (Trexima 2018). Thus, the trade unions argue that because such provisions have already been introduced in most companies 'they will hurt no one' (ČMKOS 2019b).

Employers are strongly opposed to reductions in working hours (without corresponding wage decreases) at a time when the labour market is facing a severe labour shortage (ČT24 2018; Svoboda 2018; BusinessInfo.cz 2019). However, they admit that the increases in labour productivity and changes in work organization that will accompany digitalization will allow for reductions in working hours in the future without having to decrease wages (BusinessInfo.cz 2019).

\subsection{Labour Shortages}

Labour shortages currently present a major problem for employers (for example, Dlouhý 2019; Drbalová 2019). This issue was first identified in 2014 and was accompanied by concerns that such shortages might negatively affect the growth of the Czech economy (for example, Beneš 2018). After consulting with employers, in November 2015 the Czech government approved the 'Special procedures for highly-qualified employees from Ukraine' project, the aim of which was to simplify the administrative process relating to the immigration of Ukrainian specialists. However, this project was not sufficient to cover the needs of employers who found themselves faced increasingly with a serious lack of low-skilled workers (Praks 2018). This situation was addressed several times at meetings of the tripartite body and, at the request of employers, the project was extended to include lower-skilled workers not only from Ukraine but also from Serbia and nonEuropean countries, such as India, Mongolia and the Philippines. Moreover, the quotas governing foreign workers were increased (see Figure 5.3).

The trade unions do not consider importing labour from abroad to be a good solution to the labour shortage, and note that foreign workers are arriving from countries in which wage levels are lower than in the Czech Republic and therefore they are willing to work for lower wages than are Czech employees. They opine that employers are abusing the situation and that, instead of motivating potential employees with higher wages, they are simplifying workplace processes to make it possible to recruit employees from poorer EU and non-EU countries and thus avoid increasing wages. ${ }^{28}$

The concerns of the unions in this respect are confirmed by data obtained from the Czech Statistical Office (Český statistický úřad, ČSÚ). Figure 5.4 illustrates that, since 2015, of the foreign workers in the Czech Republic, Ukrainian, Polish and Bulgarian workers receive particularly lower wages.

In September 2019, this project for importing workers from abroad was re-classified in the form of three programmes: the Qualified Employee Programme (Program kvalifikovaný zaměstnanec), the Highly-Qualified Employee Programme (Program vysoce kvalifikovaný zaměstnanec) and the Key and Scientific Personnel Programme (Program klíčový a vědecký personál), all of which are geared towards skilled and qualified workers.

\section{Reforms in the education system as a long-term solution to labour shortages}

While the social partners failed to agree on the solution to the labour shortage issue through importing labour, both sides stress that this is only a short-term solution. Both social partners agree that the long-term solution to the labour shortage lies exclusively in reform of the education system (Dlouhý 2019, Drbalová 2019; Martínek and 


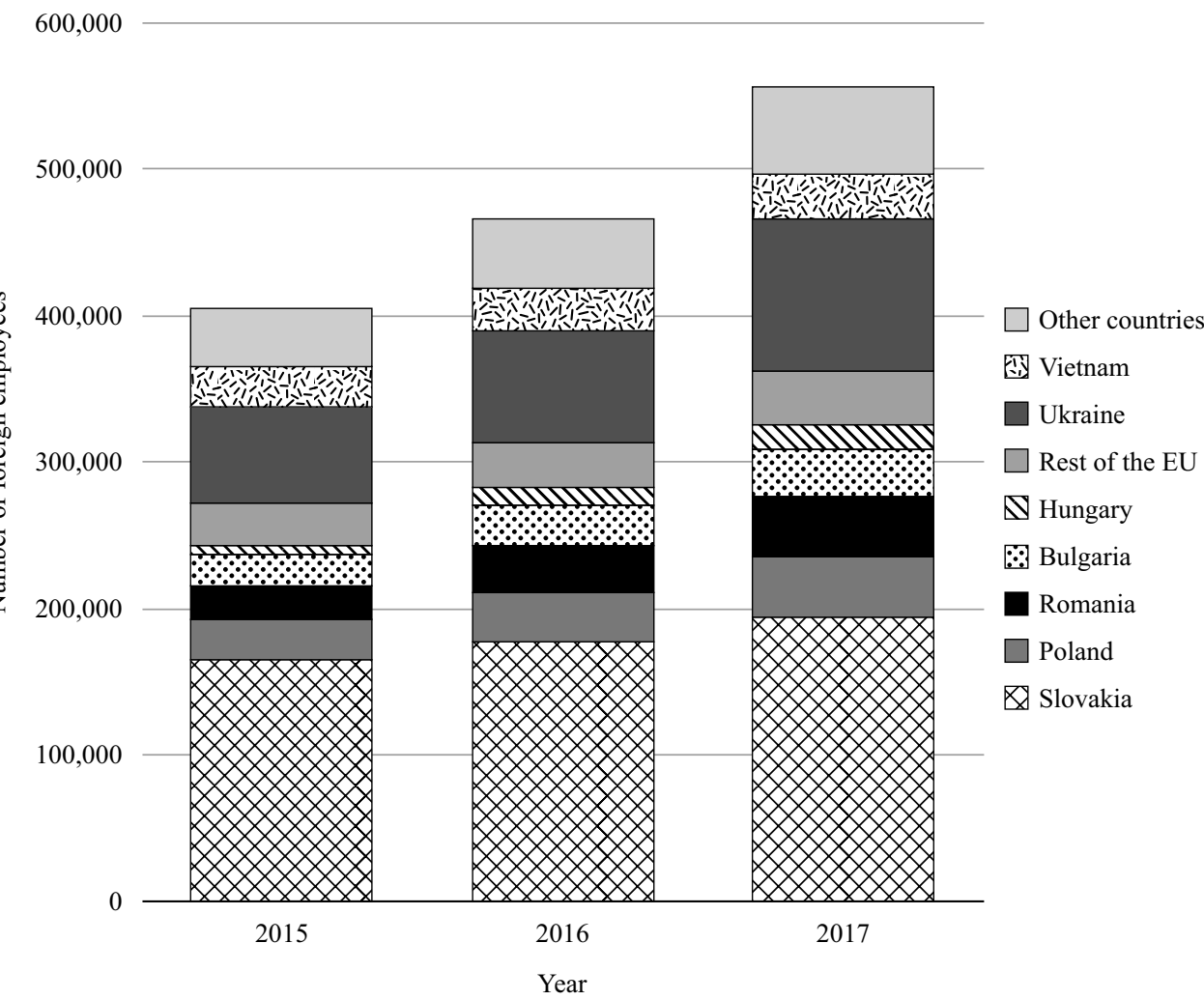

Figure 5.3 Employment of foreigners by citizenship in the period 2015-17 (at 31 December for each year)

Vejvodová 2019), which, they stress, should respond more flexibly to the demands of the new world of work. Education is discussed frequently at tripartite meetings. The social partners stress the importance of lifelong learning and retraining, which will help workers who lose their jobs as a result of digitalization to secure new positions. The SP ČR is demanding that internal company retraining should be financed from Active Employment Policy resources, ${ }^{29}$ so that employers are able to immediately retrain their employees according to their requirements (SP ČR 2019). The social partners also support dual education, that is, cooperation between vocational schools and companies that allows students to gain experience during their studies and employers to train their own employees (Martínek and Vejvodová 2019; SP ČR 2019).

The importance of education for the social partners is reflected by the National Agreement on Human Resources Development (Národní dohoda v oblasti rozvoje lidských zdrojů) ${ }^{30}$ signed by the social partners and the government during the period July to October 2015. The strategic objective of the National Agreement is to help to ensure sufficient numbers of people with the requisite skills (that is, with the relevant competences, well-prepared and in the necessary numbers and structure) in the labour market. Attaining this goal involves cooperation between employer and employee representatives, 


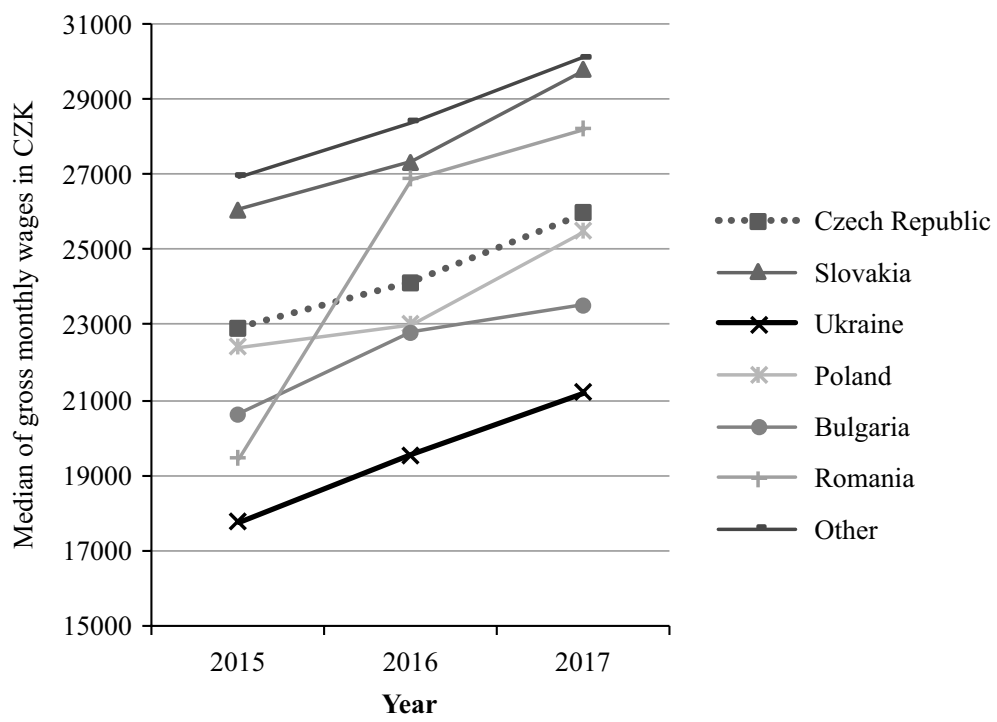

Figure 5.4 Median of gross monthly wages by citizenship, 2015-17 (in CZK)

state administration and local authorities and the relevant interest groups in the following areas: cooperation between educational institutions and companies; supporting interest in technical and handicraft subjects; the structure and optimization of the education network in its regional organization, while respecting the needs of high labour-demand sectors; and the quality of school/college leavers and the link between further education and the labour market. The National Agreement further specifies the objectives and responsibilities of the individual signatories.

Support for a strike called by the Czech-Moravian Trade Union of Workers in Education (Českomoravský odborový svaz pracovníků školství, ČMOS PŠ, a member of the ČMKOS) also demonstrated that education is a real priority for both social partners. The trade union declared a strike on 6 November 2019 following unsuccessful negotiations with the government on wage increases for teaching staff in 2020. A total of 1221 schools were closed, 2743 operated a restricted timetable and a further 3000 schools expressed support for the strikers. ${ }^{31}$ The government initially promised teachers that their salaries would be increased by a total of 15 per cent, 10 percentage points of which would be reflected in the tariff salary and 5 percentage points in extra remuneration decided by the headteacher. Subsequently, the government announced that the salaries of teachers would be increased by just 10 per cent, 8 percentage points of which would be reflected in tariff salaries and 2 percentage points in extra discretionary remuneration. The strike was supported by the CMKOS and other trade union organizations, as well as employers; the SP ČR stated that the government must keep its promise and increase teachers' salaries as originally announced as education is crucial in averting the negative impacts of new technologies on employment. The Czech Republic therefore needs high-quality and motivated teachers (SP CR 2019). However, the Minister of Education refused to comply with the demands of the strikers. 


\section{CASE STUDIES}

\subsection{Case Study 1: Gentleman's Agreement between the Government and the Social Partners on an Amendment to the Labour Code}

Both trade unions and employer representatives consider the system of social dialogue in the Czech Republic to be functional and effective. A good example is the new 'gentleman's agreement' concluded between the government and the social partners on an amendment to the Labour Code. It is the first agreement of its kind to be concluded in the Czech Republic. Although it is not legally binding and the amendment to the Labour Code has yet to go through the standard legislative process, the signing of this agreement provides evidence of a functional social dialogue system and the social partners' willingness to compromise.

The amendment to the Labour Code was published by the Ministry of Labour and Social Affairs (Ministerstvo práce a sociálních věcí České republiky, MPSV) for the first time in the summer of 2018. A subsequent version, which omitted all the provisions on which the government and the social partners disagreed, was confirmed with the conclusion of a 'gentleman's agreement' on 14 October 2019 between representatives of the government coalition and the social partners that participate in the tripartite body. All the parties consented to support the draft amendment in its agreed form and not to promote or support any other changes and proposals without mutual agreement. The agreement is intended to prevent possible delays and the addition of further changes during the course of the amendment through the Chamber of Deputies of the Parliament of the Czech Republic (Poslanecká sněmovna Parlamentu České republiky), that is, the reasons why the amendment was not discussed and adopted during the previous parliamentary session.

The Labour Code affects us all on an everyday basis. Any change must have broad support and we must be very careful concerning any improvements we might suggest. Therefore, it is very important that we were able to reach an agreement with both the trade unions and the employers. This will be the first time that a conceptual amendment has been introduced into the Labour Code in eight years commented Jana Maláčová, Minister of Labour and Social Affairs (MPSV 2019).

'It is the first time in the history of social dialogue in the Czech Republic that we have signed such an agreement with our partners', commented Jaroslav Hanák, President of SP ČR, on the agreement between the social partners (ČTK 2019).

The main changes introduced by the amendment include legislation on shared work positions, the calculation of holiday entitlement, which will be based for the first time on the number of hours worked (and not days, as previously) and changes in the posting of workers abroad). A number of provisions, such as the formula to be applied for regular increases of the minimum wage, were removed from the draft amendment since the social partners were unable to reach agreement (for more about the minimum wage see section 5.1). 


\subsection{Case Study 2 Reduction in Working Hours without Wage Cuts ${ }^{32}$}

The latest topic that the ČMKOS is considering in its 'End of Cheap Labour' campaign is reducing working hours without corresponding wage cuts. The ĊMKOS argues that Czech employees work longer hours than their counterparts in other European countries. Employer representatives do not agree to reducing working hours when they are being faced with acute labour shortages; nevertheless, they do not exclude it in the future, provided it is accompanied by increases in labour productivity.

However, the data indicate that reduced working hours have already been introduced in many Czech companies. A 2019 analysis of company-level agreements shows that working time arrangements are included in 91.7 per cent of them, 62.1 per cent of which set out uniform working hours for the whole of the organization and 29.6 per cent establish different working hours arrangements according to shift work regimes. Also, 76.9 per cent of company-level collective agreements that set out uniform working hours for the whole of the organization define a working time of 37.5 hours per week (Trexima 2019).

The reasons for reducing working hours vary according to the sector and individual companies. Many companies, principally those operating in heavy industry, have reduced working hours' regimes as a remnant of legislation from the 1980s (concerning, for example, working in carcinogenic environments). Although legislation has since changed and working conditions are no longer potentially dangerous owing to the development of new technologies, many companies have maintained reduced working hours and, moreover, have introduced it into single-shift operations, so that white-collar workers also work shorter hours. This applies, for example, to the Liberty Ostrava a.s. company which operates in the metallurgical sector and employs 6200 persons. The company-level collective agreement stipulates a working time of 37.5 hours per week for all employees except those working in the coking plant, whose working time is even shorter, at 34.25 hours (this working time regime applies to approximately 16 per cent of employees). The company has been working on reduced hours since the 1990s. Although the company has struggled with labour shortages in recent years, the management has never considered extending working hours to the length stipulated in the Labour Code (40 hours per week for single-shift work).

Similarly, the 1120 employees of AGC Flat Glass Czech a.s., a manufacturer of flat glass mainly for the construction and automotive industries, have a working time of 37.5 hours per week. The reduced working hours' regime was introduced in 2001 and applies to all the company's employees. According to the HR manager, the reduced working time constitutes a form of employee benefit. The introduction of reduced working hours was not a simple process and required extensive changes in terms of work organization; however, according to the HR manager, the changes were exclusively of a technical nature, that is, how to ensure the staffing of the various shifts in order to ensure continuous production. The company had to hire five new employees; however, this involved only a minimal increase in costs and, moreover, provided the HR manager with increased flexibility in relation to vacation and illness cover. At a time when it is difficult to find qualified workers in the labour market, it appears that this approach has reaped a number of benefits, for example, the company has a very low staff turnover rate (just 1.7 per cent in 2018) and currently has only two job vacancies. 
Vašečočky.cz, an e-shop specializing in contact lenses and accessories, reduced working hours to seven hours per day also in the form of an employee benefit. Reduced working hours were introduced in the form of a trial operation in February 2019 and have applied to all 70 of the company's employees since April 2019. The managing director stated that the reduction in working hours had not resulted in any complications and that the company's employees managed to complete their usual workload in a shorter time simply as a result of the introduction of changes in work organization. The only exception was the IT department, where the volume of work performed decreased by around 3 per cent; however, the managing director considered this to be negligible. He further stated that the eight-hour working day is an anachronism, especially in professions that require longterm concentration (Hovorková 2019; Sovová 2019).

\section{CONCLUSIONS}

Social dialogue in the Czech Republic is considered both by the social partners themselves and the professional public to be stable and to have been relatively conservative over the long term compared with other EU countries. The social partners consider the legal framework, which was established in the 1990s and has not been subjected to any fundamental changes since that time, to be both functional and effective. Relationships between the social partners and with the government are considered good; although the social partners and the government have not always agreed on the issues under discussion, the social partners generally adopt a consensual and non-confrontational behavioural style and are ready to compromise. Recently, the economic situation, involving both exceptional economic growth and low unemployment, has enabled employers to meet trade union demands for wage increases.

Currently, the social partners are particularly interested in two fundamental issues: eliminating inequalities in the labour market and labour shortages. These issues are relevant to both sides. Eliminating inequalities is more of a trade union issue, while labour shortages are of more concern to employers. In some respects, however, the social partners have the same point of view. Employers also support wage increases in some sectors (education, health and social care), while the unions are interested in solving labour shortages, preferably by way of digitalization and higher productivity than by labour immigration. In 2015, ČMKOS, the largest Czech trade union confederation, began to address inequalities, initially in terms of wage growth, via the launch of its 'End of Cheap Labour' campaign aimed at the convergence of Czech wages with the European average. In 2017, the campaign was extended to include the issue of shorter working time without corresponding wage reductions. While employers, for the most part, favour wage growth, which is being facilitated by the favourable economic situation, the shortening of working time without wage cuts is totally unacceptable at a time of acute labour shortages. The unemployment rate in the Czech Republic stood at just 2.2 per cent in October 2019 and some employers have been experiencing a shortage of labour since 2015. The employers see the most effective short-term solution as the import of labour from abroad; however, the trade unions disagree, arguing that employers recruit foreign employees from countries where wages are lower than in the Czech Republic, instead of motivating the unemployed with the offer of higher wages. In this area, however, the social partners agree that 
only the reform of the education system so that it responds better to the needs of the labour market will solve the issue of labour shortages.

According to the employers, digitalization and robotization will also help to ease labour shortages; thus, employers welcome this trend while emphasizing the need for large-scale investment. Although the trade unions indicate the potential negative effects of digitalization, they also see it as a way to raise the Czech economy from a model based on cheap labour, established in the 1990s, to a model based on modern technology, research and development. The trade unions draw attention to potential increases in unemployment in particular sectors and among particular groups of employees, and the expansion of precarious work. Moreover, they stress that the digitalization process must be regulated so that it does not pose a threat to the labour force. Against this background, the social partners agree on the need for education reform.

The main problem faced by social dialogue in the Czech Republic is the long-term decline in the trade union membership base. While the membership of employers' associations remains relatively stable, trade unions continue to record declining numbers of members. While over the past few years, some trade unions have managed to stabilize their membership bases - that is, losses in the number of members have been compensated for by the recruitment of new members, and some trade unions have even seen an absolute increase in the number of members - at this time it is difficult to predict whether this is a long-term trend or just a temporary fluctuation. If the unions fail to halt the decline in membership over the long term, they will have less and less capacity for collective bargaining.

The coverage rate of employees by higher-level collective agreements is low in the Czech Republic and it is not expected that this trend will change in the future. There are several reasons for this: employers' unwillingness to bargain collectively at the higher level, the absence of an employer partner and the misunderstanding of the importance of higher-level collective agreements as the minimum standard in the respective industry. Moreover, since many of these agreements often remain unchanged for several years, many employers consider them unnecessary (Hejduková 2007).

Although social dialogue in the Czech Republic has to face many challenges (falling trade union membership, low collective agreement coverage), there are also various positive developments, which are important for the role of social dialogue in the new world of work, especially a willingness to cooperate and compromise.

\section{NOTES}

1. Full text in English, accessed 11 October 2019 at https://www.usoud.cz/fileadmin/user_upload/ustavni_ soud_www/Pravni_uprava/AJ/23_1991_EN.pdf.

2. Full text in English, accessed 11 October 2019 at http://obcanskyzakonik.justice.cz/images/pdf/CivilCode.pdf.

3. Full text in English, accessed 11 October 2019 at https://www.legislationline.org/download/id/6742/file/ Czech_Republic_Labour_Code_2006_am2011_en.pdf.

4. Full text in English, accessed 11 October 2019 at https://www.ilo.org/dyn/natlex/natlex4.detail?p_ lang=en\&p_isn=21640.

5. Full version in English, accessed 11 October 2019 at https://www.tripartita.cz/wp-content/uploads/2017/02/ statutes_rhsd.pdf.

6. Act No. 262/2006 Coll., Labour Code, s. 286.

7. Act No. 2/1991 Coll., on collective bargaining, s. 7. 
8. There are some exceptions: it is important to note that some trade union organizations are keen to influence the representativeness criteria in certain areas. For example, in respect of members of the Police of the Czech Republic organization (Policie České republiky), the representativeness criterion was set at 40 per cent membership until 2006; that is, a trade union was allowed to operate only if it represented at least 40 per cent of police personnel at a particular unit (workplace). This provision has since been abolished; however, representatives of the Independent Trade Union of the Police of the Czech Republic (Nezávislý odborový svaz Policie České republiky, NOSP ČR) favour reintroducing representativeness criteria, for example, at 20 per cent, given that currently anyone can establish a union and, subsequently, obstruct collective bargaining. Similarly, the subject of potential trade union membership for members of the armed forces is considered from time to time (Stratilík 2010; Ozbrojeneslozky.cz 2017).

9. Act No. 262/2006 Coll., Labour Code, s. 286.

10. See the Decision of the Constitutional Court of 12 March 2008 regarding a petition to annul certain provisions of Act No. 262/2006 Coll., the Labour Code, accessed 5 November 2019 at https://www.zako nyprolidi.cz/cs/2008-116 (in Czech).

11. For the current version see the Statutes of the Council of Economic and Social Agreement of the Czech Republic, accessed 12 November 2019 at https://www.tripartita.cz/wp-content/uploads/2017/02/statutes_ rhsd.pdf.

12. For example, the KUK was not prepared to support an increase in the minimum wage without a corresponding increase in the financial resources of (particularly) municipal budgets, because without further strengthening the revenue side the continued existence of many cultural organizations would be directly threatened (Hála 2002). A further problem was that the KUK membership included a large number of self-employed persons whose interests often differ from those of employees (Húska 2019).

13. According to Samek (2019), interest in membership is growing because employees have become aware that only the trade unions can represent their interests in an effective and fully committed manner.

14. Although the ČMKOS (2019b) has reported an increase in new membership of 58592 between 2015 and 2019 , overall figures show that this has only served to compensate for the number of departing members (see section 2.3 in this chapter).

15. With 97178 members in 2019. Source: OS KOVO.

16. See https://www.oskovo.cz/os-kovo/stanovy-os-kovo (accessed 3 November 2019, in Czech).

17. Full version accessed 10 November 2019at https://ppropo.mpsv.cz/JudikatNS21Cdo26222017 (in Czech).

18. Act No. 262/2003 Coll., the Labour Code in s. 316a says that the employer may not require from an employee information that does not directly relate to work performance and the basic labour relationship. The employer may not require in particular the information on trade union organization membership.

19. Section 320a of Act No. 262/2006 Coll., the Labour Code.

20. Section 277 of Act No. 262/2006 Coll., the Labour Code.

21. 'Digitalization' does not have a uniform definition, and different authors, including the various social partners, understand it differently. Since this chapter is not only about digitalization, we do not intend to discuss individual definitions and related concepts, such as automation and robotization. Instead, we consider the term 'digitalization' in the broadest sense, as the introduction and use of digital technologies in various areas of production and wider society.

22. In 2015, the Czech Republic began to comprehensively address the issues of digitalization and its impact on economic development, in particular the consequences for the industrial sector, such as changes in the labour market and education. As part of the Action Plan for the Development of the Digital Market approved by the government in August 2015, the then Minister of Industry and Trade, Jan Mládek, initiated the compilation of a comprehensive concept and strategy known as Industry 4.0. The strategy was supported by the government-approved National Industry Initiative 4.0 report (approved in August 2016) (Vogel 2017).

23. An amendment to the Labour Code introduced in 2016 provided that the employer should meet the costs of communication between the employee and the employer and other costs when performing work outside the workplace. However, even the trade unions considered this provision to be too strict and suggested that these costs should be settled via a flat rate payment (Holanová 2016).

24. For example, according to the findings of Trexima (2017), the approach of employers to homeworking varies considerably, ranging from the total absence of specific rules to comprehensive, detailed guidelines covering working time arrangements, homeworking costs, occupational health and safety and fire protection, the protection of the employer's data and other property, and issues surrounding responsibility.

25. Employers are currently advised to conclude a detailed written agreement with the employee that covers all aspects of working outside the employer's workplace or to compile an internal regulation that covers in detail the rules applying to working outside the workplace. However, this does not change situations in which the employee suffers an accident outside the workplace and seeks compensation; in the event of a dispute, the court will be required to decide whether or not it concerns an accident suffered at work. Some lawyers (for example, Dandová 2019) consider these concerns about work-related injuries to be 
exaggerated; they opine that in the past even risk-related work (seamstresses and glassmakers) was performed as homeworking, and no case has been recorded of the abuse of injuries sustained by employees in order to increase their earnings through claiming damages.

26. According to the HK $\breve{C}$, the Act should distinguish between three categories of income: (1) occasional income - an annual income of up to CZK30 000 (or up to three times the minimum monthly wage), which would not require a trade licence or be subject to any other requirements, and which would not be taxed or subject to other deductions; (2) extra earnings - an annual income of up to twelve times the minimum monthly wage, for which it would be necessary to obtain a trade licence and for which a simplified income tax and social insurance collection regime would apply (if this income were subject to the payment of social insurance contributions at all), and this category would apply to persons who also have income from regular employment or have special social status (students, pensioners, persons on maternity or parental leave); and (3) business activities - an annual income of more than 12 times the minimum monthly wage, which would require a trade licence and that would be subject to tax and social and health insurance deductions; this category might also be entitled to the simplified tax regime as an alternative to the general (standard) tax collection regime (HK ČR 2018).

27. Bogus self-employment. The Švarc system is a Czech term used for the work of individuals who are officially self-employed, but work under the authority and subordination of the 'employer', who hired them.

28. 'I'm really looking forward to going to Germany, Austria or Belgium to attend recruitment events, and they will all be very happy to work for Czech wages!' stated Josef Středula, president of ČMKOS (Martínek and Vejvodová 2019, p. 19).

29. Currently, only the retraining of unemployed persons registered at the Labour Office is covered by the Active Employment Policy; moreover, retraining courses must be accredited by the Ministry of Education, Youth and Sports of the Czech Republic (Ministerstvo školství, mládeže a tělovýchovy Ceské republiky, MŠMT).

30. The text of the agreement is available at: https://www.socialnidialog.cz/images/stories/Sektorove_dohody/ Narodni_dohoda.pdf (accessed 8 December 2019, in Czech).

31. ČMOS, https://skolskeodbory.cz/dekujeme-vam-stavkou-nekoncime (accessed 25 November 2019).

32. The case study draws on the Reduction in Working Hours project case study, the results of which have not yet been published (for more information see https://www.vupsv.cz/en/projects/?id=342, accessed 25 November 2019).

\section{BIBLIOGRAPHY}

Beneš, M. (2018), 'Vláda vyslyšela výzvu Hospodářské komory. Schválila navýšení kvót pro Režim Ukrajina', Chamber of Commerce of the Czech Republic, Prague, 30 January, accessed 10 September 2019 at https://www.komora.cz/press_release/vlada-vyslysela-vyzvu-hospodarskekomory-schvalila-navyseni-kvot-rezim-ukrajina/ (in Czech).

Bittner, J., N. Kadlčáková, P. Haratyk and S. Volčík (2018), 'Vztah produktivity práce a odměňování ve světle pozice ČR v globálních výrobních řetězcích', unpublished OSTEU discussion paper, May.

Boháč, R., J. Morávek and J. Pichrt (eds) (2017), Sdílená ekonomika - sdílený právní problém? Prague: Wolters Kluwer.

BusinessInfo.cz (2019), 'Boj o kratší pracovní dobu vrcholí. Než ekonomika zabrzdí', BusinessInfo. $c z, 10$ June, accessed 15 September 2019 at https://www.businessinfo.cz/cs/clanky/boj-o-kratsipracovni-dobu-vrcholi-nez-ekonomika-zabrzdi-121833.html (in Czech).

Čížek, B. (2015), 'Otázky mezd a zaměstnanosti', SP ČR, 22 May, accessed 17 September 2019 at https://www.spcr.cz/images/Shrnut\%C3\%AD_mzdy_a_zam\%C4\%9Bstnanost.pdf (in Czech).

ČMKOS (2010), 'Zpráva o průběhu kolektivního vyjednávání na vyšším stupni a na podnikové úrovni v roce 2010' ('Progress report on higher-level and company-level collective bargaining in 2010'), document discussed at the ČMKOS Assembly, Prague, 23-24 November (in Czech).

ČMKOS (2015), 'Konec levné práce v ČR', ČMKOS, 19 August, accessed 27 September 2019 at https://www.cmkos.cz/cs/obsah/219/konec-levne-prace-v-cr/12791 (in Czech).

ČMKOS (2017), Prümysl 4.0, Vzdělávání 4.0, Práce 4.0 a Společnost 4.0, Prague: Sondy (in Czech). 
ČMKOS (2019a), 'Zpráva o průběhu kolektivního vyjednávání na vyšším stupni a na podnikové úrovni v roce 2019' ('Progress report on higher-level and company-level collective bargaining in 2019'), report discussed at the ČMKOS Assembly, Prague, 22 November (in Czech).

ČMKOS (2019b), 'Požadujeme růst mezd o 6-7 \%!', ČMKOS, 17 September, accessed 18 December 2019 at https://www.cmkos.cz/cs/obsah/219/pozadujeme-rust-mezd-o-6-7/170120 (in Czech).

ČT24 (2018), 'Odbory mají nový cíl: zkrácení pracovní doby o půl hodiny. Minimální mzdu chtějí hnát až na 13 700', ČT24, 27 April, accessed at: https://ct24.ceskatelevize.cz/ekonomika/2462923odbory-maji-novy-cil-zkraceni-pracovni-doby-o-pul-hodiny-minimalni-mzdu-chteji (in Czech).

ČTK (2019), 'Koalice, odbory a podnikatelé se dohodli na novele zákoníku práce', České noviny, 14 October, accessed at https://www.ceskenoviny.cz/zpravy/koalice-odbory-a-podnikatele-sedohodli-na-novele-zakoniku-prace/1809036 (in Czech).

Dandová, E. (2019), 'BOZP a práce z domu'. BOZPProfi.cz, 20 August, accessed 19 November 2019 at https://www.bozpprofi.cz/33/bozp-a-prace-z-domu-uniqueidgOkE4NvrWuNbYgYq82 yeiFzJTnBBDkvZAg_rzFJ8D5c/.

Dlouhý, V. (2019), 'Strašidlo nedostatku lidí', Blog of Chamber of Commerce of the Czech Republic, 8 February, accessed 20 November 2019 at https://www.komora.cz/strasidlo-nedostatku-lidi/ (in Czech).

Drbalová, V. (2019), Interview with Vladimíra Drbalová, Adviser to President and Director General for EU Matters and International Organizations, SP ČR, 16 September.

Fassmann, M. and J. Ungerman (2015), 'Vize změny hospodářské strategie České republiky', C̆MKOS, Prague, accessed 18 November 2019 at https://ipodpora.odbory.info/soubory/dms/ ukony/14318/6/vize-2015-cmkos_311.pdf (in Czech).

Fassmann, M., M. Myant, T. Pavelka, I. Śvihlíková, R. Hejduk, K. Smejkalová, et al. (2019), Šance na približování českých mezd vyspělé EU, Prague: Sondy, accessed 10 December 2019 at https://ipodpora.odbory.info/dms/soubory/index?file=pohledy_01-2019_20190916150323.pdf (in Czech).

Hála, J., A. Kroupa, Z. Mansfeldov, J. Kux, R. ta Vaökov and I. Pleskot (2002), 'Development of social dialogue in the Czech Republic', VÚPSV, Prague, accessed 10 December 2019 at http:// praha.vupsv.cz/Fulltext/dialen.pdf.

Hejduková, J. (2007), 'K problematice kolektivního pracovního práva z pohledu zaměstnavatelů', Sborník príspěvkủ z konference Pracovní právo 2007. 3.-5. 10. 2007, Brno: Masaryk University, accessed 20 November 2019 at https://www.law.muni.cz/sborniky/Pracovni-pravo/files/ PracPravo2007.pdf.

HK ČR (2018), 'Doporučení pro rozvoj sdílené ekonomiky. Hospodářská komora České republiky, březen 2018', accessed 7 October 2019 at https://www.komora.cz/files/uploads/2018/ 03/20180327_Doporu\%C4\%8Den\%C3\%AD-Hospod\%C3\%A1\%C5\%99sk\%C3\%A9-komoryke-sd $\% \mathrm{C} 3 \% \bar{A}$ Dlen $\% \mathrm{C} 3 \% \mathrm{~A} 9-$-ekonomice-1.pdf (in Czech).

Holanová, T. (2016), 'Velký omyl zaměstnanců. Práce z domova není benefit, varuje odborářský šéf, interview with Josef Středula, President of ČMKOS', Aktuálně.cz, 3 May, accessed 10 September 2019 at https://zpravy.aktualne.cz/finance/velky-omyl-zamestnancu-prace-z-domovaneni-benefit-varuje-od/r e2c8b4a0107011e682470025900fea04/ (in Czech).

Horváthová, J. (2019), Interview with Jessica Horváthová, Vice-President, KUK, 24 October.

Hovorková, K. (2019), 'Zkracování pracovní doby přestává být pro zaměstnance snem. Otázkou je, za jakou cenu', Aktuálně.cz, 14 May, accessed 5 September 2019 at https://zpravy.aktualne.cz/ ekonomika/pracovni-doba-se-zkracuje-nahrava-tomu-nedostatek-lidi-na-tr/r 2923f64c732611e 998d70cc47ab5f122/ (in Czech).

Húska, S. (2019), Interview with Silvester Húska, President, KUK, 24 October.

Kovanda, L. (2018), 'Platy rostou prŕliš pomalu. Na montovně přidaná hodnota nevzniká', iDNES, 10 December, accessed 17 November 2019 at https://www.idnes.cz/ekonomika/domaci/ mzdy-cesko-nezamestnanost-rust-hospodarstvi-firmy-hdp.A171205_100934_ekonomika_rts (in Czech).

Kroupa, A., R. Kyzliková, Š. Lehnmann, P. Pojer and S. Veverková (2019), 'Czech Republic: developments in working life 2018', working paper, Eurofound, 14 March, accessed 16 December 2019 at https://www.eurofound.europa.eu/country/czechia. 
Kyzlinková, R., P. Pojer and S. Veverková (2017), 'Industrial relations in the Czech Republic: recent developments and future challenges', VÚPSV, Prague.

Kyzlinková, R., P. Pojer and S. Veverková (2018), New Forms of Employment in the Czech Republic, Prague: VÚPSV, accessed 17 December 2019 at http://praha.vupsv.cz/Fulltext/vz_449.pdf.

KZPS (2019), 'Stanovisko Konfederace zaměstnavatelských a podnikatelských svazů ČR k návrhu navýšení minimální mzdy v roce 2020', KZPS, 30 October, accessed 30 November 2019 at http:// ipodpora.odbory.info/soubory/migrace/wp-content/uploads/stanovisko-k-mm-29_10_2019.doc (in Czech).

Léko, K. (2016), 'Blíží se konec žlutáckých odborů?', Lidové noviny, 18 April, accessed 15 September 2019 at https://www.pressreader.com/czech-republic/lidove-noviny/20160418/281530815193632 (in Czech).

Machovič, T. (2019), Interview with Tomáš Machovič, President NOSP ČR, 4 December.

Martínek, D. and A. Vejvodová (2019), 'Žádnou firmu jsme nepoložili' (interview with Josef Středula, President of CMKOS), Ekonom, 45, 7 November, 16-23 (in Czech).

MPSV (2019), 'Gentlemanská dohoda k novele zákoníku práce: Koalice, odbory i zaměstnavatelé si podali ruce', press release, 14 October, accessed 30 October 2019 at https://www.mpsv.cz/docu ments/20142/511219/TZ_Gentlemanska+dohoda.pdf/d41154b6-810a-e594-bc91-6ab61ada1846 (in Czech).

Ozbrojeneslozky.cz (2017), 'Měli by mít vojáci odbory? Vznikla nezávislá iniciativa, která téma otevírá, Ozbrojeneslozky.cz, 23 October, accessed 7 October 2019 at http://www.ozbro jeneslozky.cz/clanek/meli-by-mit-vojaci-odbory-vznikla-nezavisla-iniciativa-ktera-tema-otevira (in Czech).

Petříček, M. (2018), Pokud chceme vyšší mzdy, musíme být produktivnější, říká průmyslník, iDNES.cz, 7 January, accessed 15 December 2019 at https://www.idnes.cz/ekonomika/domaci/ montovna-mzdy-rozhovor-prumysl-jan-rafaj.A180105_374185_ekonomika_rts.

Praks, V. (2018), 'Tak už i nekvalifikované pracovní síly je málo, hlásí firmy', Parlamentní listy, 6 December, accessed 12 December 2019 at https://www.parlamentnilisty.cz/arena/monitor/Takuz-i-nekvalifikovane-pracovni-sily-je-malo-hlasi-firmy-562338 (in Czech).

Samek, V. (2019), Interview with Vít Samek, Vice-President, ČMKOS, 4 September.

Sekce pro evropské záležitosti Úřadu vlády ČR (2017), 'Analýza sdílené ekonomiky a digitální platforem', Analytický materiál 6/2017, accessed 10 October 2019 at https://www.vlada.cz/ assets/urad-vlady/poskytovani-informaci/poskytnute-informace-na-zadost/Priloha_4_Material_ Analyza.pdf (in Czech).

Sovová, E. (2019), 'Zkrátil zaměstnancům pracovní dobu. Osm hodin je přežitek, říká podnikatel', iDNES, 26 June, accessed 30 September 2019 at https://www.idnes.cz/finance/prace-a-podnik ani/zamestnanci-benefit-zkracena-pracovni-doba-zkusenosti-firma.A190624_095348_podnikani_ sov (in Czech).

SP ČR (2019), 'Vyzýváme vládu, aby př́ǐtí rok zvýšila platy učitelům o $15 \%$, press release, 12 November, accessed 30 November 2019 at https://www.spcr.cz/pro-media/tiskove-zpravy/13158vyzyvame-vladu-aby-pristi-rok-zvysila-platy-ucitelum-o-15 (in Czech).

Stratilík, O. (2010), 'Odbory? Vojáci si založí sdružení', Lidovky.cz, 26 October, accessed 20 November 2019 at https://www.lidovky.cz/noviny/odbory-vojaci-si-zalozi-sdruzeni.A101026_ 000021_ln_noviny_sko (in Czech).

Svoboda, M. (2018), 'Odbory mají pro ČR nový cíl: Méně práce za stejný plat!', Odbory.info, 30 May, accessed 9 November 2019 at https://www.odbory.info/obsah/5/odbory-maji-pro-cr-novycil-mene-prace-za-stejny-plat/22102 (in Czech).

Šulc, J. (2017a), 'Digitální ekonomika nemá budoucnost bez sociálního rozměru', Pohledy, 1/2017, ČMKOS, Prague (in Czech).

Šulc, J. (2017b), 'Je pro odbory sdílená ekonomika spíše šancí, nebo rizikem?', in 'Kol. autorů: Očekávaný ekonomický vývoj v roce 2018'. Pohledy, 2/2017, ČMKOS, Prague, accessed 19 November 2019 at https://ipodpora.odbory.info/dms/file/h/97982945d92783fe (in Czech).

Trexima (2016a), 'Analýza úrovně mezd v ČR', 30 November, accessed 17 September 2019 at https://www.spcr.cz/images/stories/Projekty/NORD_Analyza_urovne_mezd.pdf (in Czech). 
Trexima (2016b), 'Metoda nastavení minimální mzdy', SP ČR, accessed 15 October 2019 at https:// www.spcr.cz/images/320-Minimalni_mzda_studie.pdf (in Czech).

Trexima (2017), Problémy při práci na dálku a jejich řešení pro zaměstnance, Zlín: Trexima, accessed 5 September 2019 at http://ipodpora.odbory.info/soubory/dms/wysiwyg_uploads/ ed47d3cd5a4545ff/uploads/Problémy_při_práci_na_dálku_stud.docx.

Trexima (2018), 'Information on working conditions negotiated in collective agreements', MPSV, Prague, accessed 17 September 2019 at http://www.kolektivnismlouvy.cz/downloadEN/2018/ IPP_2018.pdf.

Trexima (2019), 'Information on working conditions negotiated in collective agreements', MPSV, Prague, accessed 18 December 2019 at http://www.kolektivnismlouvy.cz/vysledky2019EN.html.

Tůma, O. (2016), 'Očima expertů: Co si počít se sdílenou ekonomikou?', Penize.cz, 5 August, accessed 7 November 2019 at https://www.penize.cz/ekonomika/314511-ocima-exper tu-co-si-pocit-se-sdilenou-ekonomikou.

Vácha, J. (2012), 'Role sociálního dialogu a tripartity v letech 2008-2010', unpublished paper, Ministry of Labour and Social Affairs of the Czech Republic.

Vejvodová, A. (2019a), 'Z neotesaných nádeníků uhlazení lobbisté. Odboráři změnili styl, jsou úspěšní a jejich členská základna roste', Ekonom, 21 November, accessed 30 November 2019 at https://ekonom.cz/c1-66680890-odborari-meni-styl-a-jsou-efektivnejsi.

Vejvodová, A. (2019b), 'Firmy znervózňují anonymní odbory. Jejich předáci tam ani nepracují, přesto požadují veškeré údaje i plány', Ekonom, 21 November, accessed 30 November 2019 at https://ekonom.cz/c1-66680880-do-firem-se-tlaci-anonymni-odbory.

Veverková, S. (2012), 'The case of the Czech Republi', in I. Guardiancich (ed.), Recovering from the Crisis through Social Dialogue in the New EU Member States: The Case of Bulgaria, the Czech Republic, Poland and Slovenia, Budapest: International Labour Organization, accessed 6 October 2019 at https://www.ilo.org/wcmsp5/groups/public/---europe/---ro-geneva/---sro-budapest/docu ments/publication/wcms_203443.pdf.

Vogel, S. (2017), 'Addressing digital and technological change through social dialogue', Eurofound, 30January, accessed8October2019athttps://www.eurofound.europa.eu/publications/report/2017/ eu-member-states/addressing-digital-and-technological-change-through-social-dialogue.

Vyoral, T. (2017), 'Regulace sdílené ekonomiky je nepřehledná a těžko vymahatelná', Ekonomický magazín, 19 September, accessed 15 October 2019 at https://www.ekonomickymagazin. cz/2017/09/regulace-sdilene-ekonomiky-je-neprehledna-a-tezko-vymahatelna/. 